\title{
Pemikiran Politik dan Kenegaraan Mohammad Natsir
}

\author{
Mohammad Natsir's Political Thought and Nationalism
}

ABDULLAH FIRDAUS*, MOHD. NASIR OMAR \& IDRIS ZAKARIA ${ }^{1}$

\begin{abstract}
Soon after gaining independence, discourse on making Syariah as a constitutional basis of state in Indonesia was widely regarded as a trending topic to discuss among politicians, Mohammad Natsir was one of them. This article aims to explore the political thought and the principle of government and state in the point of view of Mohammad Natsir. An approach carried on this study is using descriptive analysis and content analysis by focusing on documents and writings of the object studied. After a long study to his view, it shows that the concept of Islamic state, is not mere theoretical, as it's practically applicable. The legal sovereignty upon Islamic state lies in its divine guidance which guarantees security, prosperity and justice to all people. Due to accepting the sovereignty of God as foundation for the constitution. Besides, government rules are supported by Islamic nationalism and theistic democracy guided by the principle of the unity of God (tawhid).
\end{abstract}

Keywords: democracy, Islamic state, politics, Mohammad Natsir, nationalism

Wacana pembentukan dasar perlembagaan negara berasaskan Islam pasca kemerdekaan Indonesia, tepatnya pada era presiden pertama Republik Indonesia iaitu Soekarno, merupakan babak yang penting dalam sejarah Indonesia. Dari sudut pandangan sosial, fenomena ini adalah perkara yang wajar, memandangkan majoriti penduduk Indonesia adalah beragama Islam. Faktor agama dan keyakinan tersebut sangat berperanan dalam membentuk sikap dan pemikiran seseorang meliputi persoalan sosial, ekonomi mahupun persoalan politik (Dwi Purwoko et al. 2001). Perkara ini juga berlaku ke atas Mohammad Natsir, apabila beliau berpendirian bahawa merealisasikan nilai Islam dalam hidup ini merupakan sebuah ideologi dan cita-cita utama seorang Mukmin. Menurut Natsir, ia tersimpul dalam maksud ayat al-Quran surah Al-Dhariyat (51:56) وما خحقت الجحن والإنس إلاليعبدون yang bermaksud: “Dan tidaklah Aku ciptakan jin dan manusia melainkan untuk menyembah kepada-Ku". Makna li ya 'budun (ليعبدون) menurut Natsir ialah memusatkan penyembahan hanya kepada Allah (s.w.t.) iaitu menjalankan semua aspek hidup ini sesuai dengan kehendak-Nya, sama ada perkara yang bersangkutan $h a b l$ min Allah (segala persoalan ibadah yang berkaitan langsung dengan Tuhan) dan habl min al-nas (segala bentuk persoalan yang berhubungan dengan manusia termasuk di dalamnya yang berhubungan dengan alam dan persekitaran). Perkara ini jelas sebab cita-cita sejati seorang Mukmin adalah untuk mencapai kejayaan di dunia dan akhirat (Mohammad Natsir 2001, 2008; Anwar Haryono 2001). Paparan tersebut menunjukkan bahawa dalam pandangan Natsir, isu-

\footnotetext{
${ }_{1}^{1}$ Abdullah Firdaus*(Corresponding author), Ph.D. Candidate, Dept. of Theology and Philosophy, Faculty of Islamic Studies, Universiti Kebangsaan Malaysia, 43600 BANGI, Selangor, Malaysia; Mohd. Nasir Omar, Ph.D., Professor, Dept. of Theology and Philosophy, Faculty of Islamic Studies, Universiti Kebangsaan Malaysia, 43600 BANGI, Selangor, Malaysia, email: abunasir@ukm.edu.my; Idris Zakaria, Ph.D., Professor, Dept. of Theology and Philosophy, Faculty of Islamic Studies, Universiti Kebangsaan Malaysia, 43600 BANGI, Selangor, Malaysia, email: aris@ukm.edu.my.
} 
isu yang berhubungan dengan persoalan politik dan persoalan negara termasuk dalam kerangka ibadah yang lebih luas maknanya.

Natsir dibesarkan di tengah Masyarakat Minangkabau iaitu di Kota Alahan Panjang pada 17 Julai 1908, yang persekitarannya memegang teguh adat istiadat. Ayahnya bernama Idris Sutan Saripado dan ibunya bernama Khadijah. Alahan Panjang dikenal sebagai kota yang banyak melahirkan gagasan pembaharuan. Sejak awal, penduduk kota ini telah didedah dan dilatih untuk mengenal nilai dasar Islam melalui kebiasaan dan adat resam suatu norma folkways (Kahin 1995). Demikian pula yang dialami oleh Natsir, semenjak kecil beliau sudah terbiasa mendengar perbahasan dan perbincangan ilmiah mengenai Islam yang berlaku antara golongan tradisional (kaum tua) dan golongan pembaharuan (kaum muda). Di usia 8 tahun, Natsir mula mendapat pendidikan di HIS (Holladsch Inlandsche School) pada 1916-1923. Sekolah rendah ini didirikan pada 23 Ogos 1915 oleh Haji Abdullah Ahmad, seorang tokoh pembaharuan di kota Padang, kemudian Natsir berpindah ke sekolah HIS di Solok. HIS merupakan sekolah rendah yang menggunakan bahasa Belanda. Didikan yang penuh kedisiplinan di sekolah ini telah banyak menyumbang kepada pembentukan karakter Natsir (Suhelmi 2002; Gamal 2003). Di samping itu, Natsir juga belajar agama di Madrasah Diniyah serta belajar bahasa Arab dan al-Quran daripada Tuanku Mudo Amin (Dwi Purwoko 2001). Pada tahun 1923-1927, Natsir melanjutkan pelajaran di sekolah menengah MULO (Meer Uitgebreid Lager Onderwijs) di Padang. Di sekolah ini, Natsir bergabung dengan satu perhimpunan pemuda yang bernama Jong Islamieten Bond (JIB). Ia merupakan gerakan pemuda dari kalangan terpelajar. Selain mengajarkan politik dan berorganisasi, perhimpunan ini juga memberikan latihan kepimpinan. Polisi dan idealisme perhimpunan ini sangat dipengaruhi oleh Haji Agus Salim, seorang tokoh intelektual Muslim dan pemimpin berpengaruh Sarekat Islam. Beliau banyak memberi sentuhan nilai Islam kepada perhimpunan ini (Haryono 1995; Gamal 2009; Suhelmi 2002; Deliar 1980).

Pada 1927-1930 Natsir melanjutkan pengajiannya di AMS (Algemene Middelbare School) di Bandung dan berjaya menguasai bidang kesusasteraan klasik Barat. Selepas tamat dari AMS, Natsir mendalami pengajian agama daripada Ustaz Ahmad Hassan dan sekaligus bergabung dengan PERSIS. Pertubuhan ini melihat Islam bukan setakat agama yang mengurus persoalan ritual ibadah secara kepada Tuhan saja, malah Islam merupakan sebuah sistem politik dan sosial. Semasa aktif di PERSIS (Persatuan Islam) Natsir berpeluang untuk mengekspresikan pemikirannya menerusi majalah Pembela Rakyat milik PERSIS dengan nama samaran A. Muchlis (Deliar Noer 1980; Dwi 2001; Ahmad 1954; Dwi Purwoko 2001). Di samping itu, Natsir juga sangat aktif membabitkan diri dalam perhimpunan JIB cawangan Bandung. Pada tahun 1932, beliau mendirikan yayasan Pendidikan Islam (PENDIS) di Bandung (Haryono 1995; Kahin 1995; Suhelmi 2002). Pelbagai nama telah diberikan kepada Natsir. Beliau digelar sebagai 'pembawa hati nurani umat', 'seorang guru', 'seorang tokoh yang universalis', 'pejuang yang merangkumi dua peradaban' (Harjono 2001), 'the last giant among the indonesia's nationalists and revolutionary political leaders' (Kahin 1970), 'the second grand old man' sesudah H. Agus Salim untuk penglibatan proaktif di dunia Islam (Amin Rais 1988), 'pendakwah yang teguh', 'negarawan yang mulia', 'politikus yang jujur' dan 'pejuang yang ikhlas' (Susilo 2008). Begitu banyak gelaran dan anugerah yang disandangkan kepada Natsir. Ini menunjukkan perakuan orang ramai ke atas integriti dan kredibiliti beliau.

\section{Islam dan Politik}

Islam sebagai agama dan dasar keyakinan telah menjadi falsafah hidup dan ideologi seorang Mukmin. Ia tidak akan pernah dapat dipisahkan daripada aktiviti kehidupan mereka. Bagi orang Mukmin, al-Quran telah menjadi undang-undang dan peraturan yang mengatur seluruh aspek dan dimensi hidup mereka. Namun sebagaimana undang-undang yang lain, al-Quran juga tidak dapat berdiri dengan sendirinya tanpa ditopang dengan satu lembaga yang menguatkuasakan 
perundangan itu secara utuh, dalam situasi seperti inilah peranan negara diperlukan. Dalam sebuah artikel Arti agama dalam negara, Natsir menegaskan perhubungan yang kuat antara agama dan politik dengan mengatakan:

\begin{abstract}
Jika yang dinamakan agama itu hanyalah semata-mata satu sistem peribadatan antara makhluk dengan Yang Maha Kuasa. Definisi ini tidak tepat bagi agama yang bernama Islam. Islam adalah falsafah hidup; satu sistem perikehidupan untuk kemenangan manusia sekarang dan di akhirat nanti. Oleh kerana itu, bagi kita sebagai Muslim kita tidak mungkin dapat melepaskan diri kita daripada politik. Sebagai orang berpolitik, kita tidak dapat melepaskan diri daripada ideologi kita, yakni ideologi Islam (Mohammad Natsir 2008a).
\end{abstract}

Daripada kenyataan di atas, dapat difahami bahawa dalam pandangan Natsir, makna berpolitik mengimplikasikan sebahagian daripada makna beragama. Jika diterokai secara mendalam, didapati pemikiran politik Natsir terbahagi kepada dua bahagian. Pertama, prakemerdekaan Indonesia. Dalam fasa ini corak pemikiran politik beliau lebih cenderung ke arah idea dan aksi untuk merebut kemerdekaan daripada penjajah Belanda yang Kristiani. Kritikan tajam terus dilontarkan oleh Natsir ke atas sikap dan polisi kerajaan Belanda yang cenderung mendiskriminasi umat Islam Indonesia dengan menyokong gerakan Kristianisasi, seperti memberi dana yang besar kepada umat Kristian untuk mendirikan rumah-rumah kebajikan, kemudahan pendidikan, rumah ibadah dan bantuan kesihatan dalam usaha mereka mengkristianisasi umat Islam. Dalam masa yang sama, kerajaan Belanda sama sekali tidak memerhatikan kepentingan umat Islam (Mohammad Natsir 1969). Kedua, pasca-kemerdekaan Indonesia. Iaitu pada awal era kepimpinan presiden Soekarno. Pada ketika itu banyak berlaku polemik dan konflik di parlimen antara pemimpin yang berhaluan sekular dan neutral agama (liberal) dengan parti yang berbasis Islam, berkenaan dengan ideologi dan dasar negara Indonesia. Secara khas polemik terbuka yang berlaku antara Soekarno yang berpandangan nasionalis-liberal melawan Natsir yang berpandangan Islam (Mohammad Natsir 2008b).

Pada pasca kemerdekaan itu, kita dapati bahawa Natsir begitu teguh untuk menegakkan nilai Islam di dalam lapangan politik. Sebagai ketua parti Muslim terbesar pada ketika itu yakni Parti Masyumi, Natsir yang ketika itu juga menjawat sebagai ahli parlimen melibatkan diri secara langsung dalam panggung politik. Dasar pandangan politik Natsir mengacu kepada prinsip tauhid atau kedaulatan Tuhan. Menurut beliau, hakikat tauhid mengimplikasikan 'penyerahan mutlak diri seseorang kepada Allah (s.w.t.) dan memerdekakan jiwanya daripada pelbagai penghambaan sesama makhluk'. Tauhid juga merefleksikan keteguhan hati, ketenangan spiritual, kecerdasan intelektual dan perpaduan universal sesama umat manusia. Asas tauhid ini memiliki dua aspek yang teguh. Aspek pertama, ia memperkukuh kesedaran batin, menumbuhkan spritualiti dan menjadi asas etika peribadi. Manakala aspek kedua, ia mengajarkan makna perpaduan universal bagi umat manusia yang berdasarkan persamaan, keadilan, kasih sayang, toleransi dan kesabaran. Natsir mengisyaratkan begitu pentingnya peranan tauhid dalam kehidupan seorang Mukmin, sehingga maju dan mundurnya umat Islam itu sangat bergantung kepada bagaimana pemahaman dan penghayatan mereka ke atas doktrin tauhid tersebut (Mohammad Natsir 2008; Yusril 1995). Natsir juga memaparkan kepentingan pendekatan politik terkini dalam konteks Islam bagi memenuhi sebarang keperluan semasa yang berkenaan dengan urusan pentadbiran negara. Gagasan politik Islam yang dibawa oleh Natsir berorientasikan kepada wahyu yang sesuai dengan kepentingan dan realiti sosial masyarakat masa kini. Menurut seorang murid kepada Natsir, Yusril Ihza Mahendra (1995), gerakan modenisme politik Islam yang dibawa oleh Natsir itu sebagai suatu sikap dan pandangan yang berusaha untuk menerapkan ajaran dan nilai kerohanian yang terkandung di dalam al-Quran dan al-Sunnah dan menyesuaikannya dengan perkembangan-perkembangan mutakhir dalam sejarah peradaban manusia. 
Dalam penulisan Mungkinkah al-Quran mengatur negara?, Natsir menyimpulkan bahawa bagi memutuskan perkara-perkara yang berkaitan dengan urusan keduniaan, tapi secara spesifik tidak terdapat dalam teks agama, maka para pakar hukum Islam dengan potensi dan autoriti keilmuan yang mereka miliki, dapat melakukan ijtihad bagi mengeluarkan pandangan hukum secara musyawarah, sesuai dengan keperluan semasa dengan berlandaskan kepada alQuran dan al-Sunnah. Dalam hal ini Natsir menegaskan:

\begin{abstract}
Adapun urusan-urusan yang di luar hal-hal yang ditetapkan agama, semuanya boleh kita atur menurut keadaan zaman, dengan cara-cara yang munasabah, dan tidak melanggar hukum-hukum yang telah ditetapkan. Boleh diadakan peraturannya dengan ijtihad di zaman kita sekarang, disusun dengan permusyawaratan antara orang-orang ahli (pakar) dalam masing-masing urusan (Mohammad Natsir 2008).
\end{abstract}

Perkara-perkara yang dimaksudkan di atas, juga merangkumi peraturan yang berkenaan dengan pentadbiran negara seperti pengurusan dalam bidang ekonomi, pendidikan ataupun kesihatan. Pada pandangan Natsir, perkara yang demikian itu bersifat tidak tetap selalu berubah-ubah sesuai dengan tuntutan zaman dan keadaan. Oleh kerana itu, boleh sahaja pemerintah Islam mengambil contoh peraturan daripada mana-mana pihak selama ia tidak bercanggah dengan dasar agama dan memberi kebaikan kepada kehidupan bernegara. Dalam ijtihad, atau ketika mengambil contoh dari orang lain, atau dalam menyusun peraturan yang baru itu, kaum Muslimin haruslah sentiasa memakai wahyu Ilahi dan Sunnah Rasul untuk dijadikan ukuran dan kriterium, untuk menyaring manakah yang boleh dipakai dan manakah yang harus disingkirkan (Mohammad Natsir 2008; Asad 1999).

\title{
Konsep Negara Islam
}

Dalam pidato rasmi selaku ketua Parti Masyumi sekaligus Perdana Menteri dalam sidang Pleno Konstituante pada tarikh 12 November 1957, Natsir menyatakan bahawa konsep negara Islam itu berdasarkan kepada hukum Tuhan yang sempurna, dengan prinsip toleransi dan rasa saling menghargai ke atas pelbagai kelompok dan golongan yang berbeza faham dan keyakinan. Secara tegas beliau mengkritik pemahaman keliru yang berlaku pada sebahagian orang dalam memahami pengertian negara Islam. Ramai yang beranggapan bahawa negara Islam itu identik dengan harem, pemimpin jahil yang cenderung hedonistik yang memakai topeng agama sebagai alat untuk menipu rakyat bagi memenuhi kepentingan peribadi atau kelompoknya sahaja. Sehubungan dengan fenomena ini, Natsir mengatakan:

Kalau kita mengatakan bahawa agama dan staat (negara) harus bersatu, sudah terbayang di mata, satu bahlul (bloody fool) duduk di atas singgasana, dikelilingi oleh 'harem-nya' menonton tarian 'dayang-dayangnya' dan lain-lain. Terbayangbayang olehnya yang duduk mengepalai 'minister' (kementerian) kerajaan beberapa orang tua bangka memakai sorban besar, memegang tasbih sambil meminum hoga ... Bagi orang Eropah, Khalifah=harem, Islam=poligami (Mohammad Natsir 2001; Gunawan 2000).

Menurut Natsir, dalam perspektif Islam, berdirinya sebuah negara Islam bukanlah sebagai tujuan akhir, namun yang menjadi matlamat ialah 'berlakunya undang-undang Ilahi secara sempurna sama ada yang berkenaan dengan perikehidupan manusia sebagai individu ataupun sebagai anggota masyarakat, sama ada yang berkenaan dengan kehidupan dunia ataupun yang berhubungan dengan kehidupan akhirat' (Mohammad Natsir 2001). Pandangan tersebut selari dengan apa yang dikemukakan oleh para pemikir Islam terdahulu seperti alMawardy dalam Al-Ahkam al-Sultaniyyah, begitu juga dengan Ibn Taymiyyah dalam al-Siyasah al-shar iyyah, yang menyifatkan kewajipan negara adalah untuk memelihara agama rakyatnya. 
Begitu juga pandangan Muhammad Asad dalam The Principles of state and government in Islam yang menyebutkan bahawa matlamat akhir negara itu dalam perspektif Islam adalah bagi melestarikan bingkai kerja politik dan kerjasama bagi umat Islam, sebagaimana yang ditegaskan oleh surah Ali 'Imran (2:103-104). Negara itu sendiri bukan menjadi matlamat akhir, ia hanya bermaksud untuk mewujudkan kesejahteraan rakyat yang berdasarkan persamaan, keadilan dan amar ma'ruf nahi munkar (al-Mawardy 1989; Ibn Taymiyyah 1991; Ibn Khaldun t.th.; Muhammad Asad 1999). Kewujudan sebuah negara semestinya mencerminkan keperibadian rakyatnya. Oleh sebab itu menurut Natsir, terbentuknya sebuah negara semestinya mempunyai akar yang tertanam kuat dalam masyarakat. Ini kerana hubungan antara negara dengan rakyat sangat berintegrasi, ibarat hubungan isi kandungan dengan bentuk (al-'ard wa al-jawhar). Ini memandangkan negara merupakan cerminan nilai dan fahaman-fahaman yang wujud dalam masyarakat, dan masyarakat pula merefleksikan nilai dan dasar-dasar luhur suatu negara (Mohammad Natsir 2001).

Natsir menegaskan bahawa Islam hanya memberikan dasar-dasar pokok saja untuk pembentukan dan pengurusan negara. Perkara itu sesuai dengan tabii manusia sepanjang masa. Islam tidak mengatur seribu satu perkara-perkara detail yang bersifat teknikal. Oleh sebab itu, bentuk dan sistem perlembagaan negara secara teknikal dan terperinci tidak ditentukan oleh Islam (Mohammad Natsir 2008b, 2001). Dalam konteks ini juga, Natsir bersetuju dengan konsepsi Muhammad Iqbal yang memandang bahawa Islam bukan sekadar agama sahaja. Islam juga bererti negara dengan 'seperangkat struktur hak kewajipan yang hidup di tengah-tengah masyarakat yang memiliki dasar etika'. Ini bermakna, idealisme Islam berkait rapat dengan pentadbiran sosial yang ia ciptakan. Oleh sebab itu, al-Quran menganggap perlu untuk menyatukan agama dan negara, etika dan politik dalam satu wadah wahyu (Mohammad Natsir 2001; Iqbal 1948, 2006).

Menurut Natsir, sistem pemerintahan negara Islam bukan berbentuk teokrasi, yang bermaksud satu sistem negara yang dipimpin oleh priesthood (sistem kepaderian) di mana pemegang kekuasaan dipandang sebagai wakil Tuhan di muka bumi. Menurut Natsir lagi, negara Islam adalah negara demokrasi dalam pengertian anti istibdad (despotisme), anti absolutisme dan anti sewenang-wenang, tetapi bukan juga negara yang berbentuk demokrasi sebagaimana yang dikonsepsikan oleh Barat, iaitu sebuah sistem negara yang berdasarkan kesepakatan dan selera dari rakyat semata-mata. Tetapi negara demokrasi Islam itu memiliki pengertian sebuah negara yang 'dibina atas dasar kesepakatan, musyawarah, keadilan dan toleransi yang berpedomankan kepada al-Quran dan al-Sunnah dengan maksud untuk meraih kesejahteraan di dunia mahupun di akhirat'. Natsir menyebutnya dengan istilah theistic democracy di mana agama dan negara berintegrasi antara satu dengan yang lainnya (Mohammad Natsir 2001, 2008b; Deliar 1980).

Secara eksplisit, Natsir mengetengahkan pengertian sebuah negara dengan mengemukakan syarat-syarat dan karakteristik yang terkandung dalam pengertian yang dimaksudkan. Menurut Natsir, 'negara adalah sebuah institusi yang mempunyai hak, tugas dan tujuan yang khusus'. Melalui institusi ini, segala kepentingan yang berkenaan dengan pentadbiran negara disalurkan. Negara juga merupakan institusi yang menjamin tumbuhnya nilai kebaikan dan kerjasama sosial sebagaimana yang terimplikasi dalam prinsip tauhid. Sebagai sebuah institusi, negara harus mempunyai beberapa elemen iaitu wilayah, rakyat, pemerintah dan kedaulatan undang-undang perlembagaan atau suatu sumber hukum dan kekuasaan lain yang tidak tertulis. Adapun kekuasaan dan kewenangan sebuah negara, menurut Natsir pula meliputi seluruh masyarakat dan segala institusi yang terdapat di dalamnya, mengikat ataupun menyatukan institusi-institusi itu dalam suatu peraturan hukum, menjalankan koordinasi dan regulasi dari seluruh bahagian masyarakat, mempunyai hak untuk memaksa anggotanya mentaati segenap peraturan dan hukum yang telah ditetapkan negara, dan mempunyai tujuan untuk memimpin, memberi bimbingan dan memenuhi keperluan rakyat secara keseluruhan (Mohammad Natsir 2008b). Bagi merealisasikan kehidupan bernegara yang 
baik dengan rakyat yang harmoni, sejahtera dan bertanggungjawab, maka prinsip pentadbiran negara harus memiliki anasir seperti prinsip nilai universal yang terkandung dalam prinsip tauhid, bagi membina perpaduan dan membangun kesedaran individu dan masyarakat, prinsip kebangsaan yang berdasarkan kepada persamaan keimanan, prinsip kesejahteraan dan solidariti ekonomi yang berasaskan keadilan dan menghormati hak orang lain, prinsip toleransi dan rasa hormat terhadap perbezaan keyakinan yang ada di tengah-tengah masyarakat (Sohirin 2013).

Natsir juga merumuskan asas kekuatan negara Islam berdasarkan kepada prinsip tauhid iaitu kedaulatan Tuhan yang menyebabkan rakyat menyimpan perasaan takwa kepada Tuhan, ketaatan rakyat ke atas hukum-hukum negara sebagai manifestasi makna tauhid, rasa pengakuan kepada kedaulatan Tuhan yang mutlak, dan falsafah dasar perlembagaan negara itu harus berlandaskan kepercayaan kepada kedaulatan Tuhan yang mutlak sebagai sumber hukum dan menjadi gravitational center bagi segala-galanya (Mohammad Natsir 2008). Jadi, konsep negara Islam dalam perspektif Natsir memiliki karakteristik dan nilai yang unik, yang tidak hanya berorientasi kepada kepentingan semasa dan bersifat sementara. Tetapi ia bersifat universal yang dapat diterima pakai oleh semua kelompok dan golongan sepanjang masa menerusi prinsip kedaulatan Tuhan sebagai sumber hukum dan etika bernegara. Jika ditelaah lebih mendalam, didapati konsepsi Natsir mengenai negara Islam, memiliki konotasi kedaulatan hukum (syariah) dan kedaulatan politik. Kedaulatan hukum berteraskan syariah dan petunjuk al-Quran dan Sunnah Nabi. Sementara kedaulatan politik diserahkan kepada rakyat melalui saluran shura secara demokrasi. Dalam konteks ini, rakyat diberi kebebasan untuk menentukan sistem dan teknik pentadbiran ataupun pemilihan pemimpin.

\section{Karakteristik Pemimpin Negara}

Menurut Natsir, dalam Islam pemimpin dan rakyat sama-sama memiliki hak dan kewajipan antara satu atas yang lainnya. Oleh sebab itu, 'keseimbangan antara perlindungan hak asasi manusia dengan pelaksanaan kewajipan (human duties) antara negara dan rakyat menjadi dasar penting bagi mewujudkan kestabilan hidup bernegara. Nama dan sebutan yang dianugerahkan kepada seseorang yang menjawat ketua negara, dalam pandangan Natsir, bukan menjadi syarat penting dalam konsep politik Islam, selama sifat-sifat, hak dan kewajipannya sesuai dengan Islam (Mohammad Natsir 2001, 2008). Adapun kriteria penting yang mesti dimiliki oleh seorang pemimpin negara itu adalah agama, akhlak dan kemampuannya untuk memimpin. Sehubungan itu, Natsir menyebut:

\footnotetext{
Ditetapkan yang menjadi kriterium atau ukuran untuk melantik seseorang menjadi kepala negara adalah agamanya, sifat dan tabiatnya, akhlak dan kecakapannya (kemampuannya) untuk memegang kekuasaan yang diberikan kepadanya. Jadi bukanlah bangsa dan keturunannya ataupun semata-mata inteleknya saja (Mohammad Natsir 2008).
}

Menurut Natsir, para pemegang kekuasan negara merupakan ulu al-amr yang wajib ditaati berdasarkan surah al-Nisa (2:59-59). Dalam masa yang sama, ulu al-amr sebagai pemimpin memiliki kewajipan-kewajipan antaranya amanah, adil dan musyawarah berdasarkan pada ayat al-Quran surah al-Shura (42:38). Konsep kepimpinan dan kriteria seorang pemimpin yang digagaskan oleh Natsir dalam hal ini serupa dengan pandangan Ibn Taymiyyah dalam al-Siyasah al-syar iyyah ketika menjelaskan tentang kewajipan para penguasa dan rakyat. Antaranya ialah amanah, memiliki ilmu pengetahuan dan berkemampuan (Mohammad Natsir 1987; Ibn Taymiyyah 2009). Ini kerana urusan pentadbiran negara merupakan perkara yang serius. Oleh sebab itu integriti, kredibiliti dan amanah menjadi kriteria yang sangat penting yang mesti dimiliki seorang ketua negara. 


\section{Kebangsaan Umat Islam (Nasionalisme Islam)}

Rakyat merupakan elemen penting bagi mewujudkan sebuah negara, bahkan kekuatan suatu negara sangat ditentukan oleh kualiti perpaduan di kalangan rakyatnya. Proses perpaduan rakyat yang bersepakat untuk hidup bersama dan bekerjasama sudah pasti memerlukan suatu alasan yang kuat. Antara alasan untuk mengikat perpaduan tersebut ialah bahasa, budaya ataupun agama. Ikatan ini pula menjadi fahaman yang mendorong semangat keberlangsungan sesebuah negara. Fahaman itu disebut sebagai fahaman kebangsaan atau semangat nasionalisme. Dalam konteks ini dapat difahami bahawa nasionalisme sebagai refleksi semangat perpaduan kebangsaan menjadi faktor penting bagi menjamin keberlangsungan sebuah negara.

Natsir berhujah bahawa keinginan untuk membina perpaduan kebangsaan itu adalah perkara yang semula jadi wujud dalam diri manusia sebagaimana yang diisyaratkan oleh sebuah hadis yang diriwayatkan dari Nabi (s.a.w.) yang difahami bahawa menyintai negara merupakan sebahagian daripada iman. Konsep nasionalisme yang dipaparkan oleh Natsir mengimplikasikan rasa cinta negara dan pembelaan terhadap tanah air. Dalam pengertian yang jelas, ia merupakan suatu perpaduan atau ikatan kebangsaan yang tidak dicemari oleh taksub yang berpotensi memutuskan tali ukhuwah dan mencetuskan kebatilan, bukan pula bentuk nasionalisme chauvinistic (asabiyyah jinsiyyah) yang memuja tanah air secara berlebihan dan menjurus ke arah taksub yakni spirit of the clan yang sempit ataupun `asabiyyah yang mengarah kepada tindakan kezaliman. Pengertian `asabiyyah yang seperti ini ditolak oleh Islam. Bahkan Islam menolak bentuk fahaman 'asabiyyah (fanatik perkauman) dan semangat kebangsaan (nasionalisme) yang melampau dan memuja-muja bangsa sendiri sehingga berlaku zalim dan menyekat hak orang lain (Mohammad Natsir 2001; Solihin 2013; Burhan Djabir 2008; Asad 1999; Noer 1980). Dalam konteks ini, Natsir mengisyaratkan ada semangat nasionalisme yang diakui oleh Islam iaitu yang tidak mengandungi taksub dan ada juga bentuk nasionalisme yang ditolak oleh Islam iaitu 'asabiyyah jinsiyyah yang mengarahkan seseorang berbuat zalim serta menyekat hak golongan lain.

Natsir berpendapat bahawa dasar perpaduan dan kebangsaan umat Islam adalah kesatuan daripada segi agama dan keyakinan yang sama, untuk hidup bersama-sama. Hal ini merujuk kepada surah al-Hujurat (49:10) yang bermaksud: "Sesungguhnya orang-orang mukmin itu tidak lain, melainkan saudara kepada yang lain, oleh sebab itu damaikanlah di antara dua saudara kamu dan takutlah kepada Allah agar kalian diberi rahmat". Kesatuan daripada segi agama dan akidah ini mendorong setiap individu untuk hidup bersama dan menciptakan keselamatan serta kesejahteraan bagi semua individu dalam sebuah negara. Natsir bersetuju dengan pandangan Lothrof Stoddard dalam The New World of Islam yang menyifatkan bahawa kebangsaan atau nasionalisme umat Islam itu merupakan: "A state of mind (satu keadaan jiwa) satu keyakinan teguh oleh satu golongan manusia yang besar, mereka secara bersama-sama mendirikan satu nasionalisme, satu perasaaan yang sama masuk golongan satu bangsa" (Mohammad Natsir 2001). Daripada kenyataan tersebut, didapati pengertian 'kebangsaan' atau 'nasionalisme' dalam pandangan Natsir meliputi makna 'satu semangat, satu keyakinan, satu warisan kenangan yang secara bersama-sama untuk dipusakai dan dimiliki, di samping keinginan untuk hidup secara bersama-sama dengan cita-cita yang sama'. Dalam hal ini, Natsir mengutip pendapat Ernest Renan yang menyebutkan dalam pidatonya semasa di Sorbonne pada tahun 1882: "Kebangsaan adalah satu semangat, satu kaedah rohani yang didirikan oleh tarikh dan kenangan kepada kemuliaan masa lalu serta kerukunan bersama yang terus hidup dan cita-cita untuk hidup dan mati bersama yang didorong oleh cita-cita yang sama untuk menghargai dan menjujung tinggi warisan harta pusaka bersama". (Natie un principe spirituel la possesion en commun d'un eiriche legs de souvenir le consentement acruel Le desire de vivre ensamble, la valonte de continuer a faire valoir l'heritage quo'on apercu indivis) (Natsir 2001). 
Oleh sebab itu, 'ikatan rohani' dari rasa kebangsaan semacam ini menurut Natsir sudah semestinya akan melampaui batas negara, bahasa, warna kulit dan perbezaan yang tidak asas. Konsep kebangsaan seperti ini lebih berkonotasi kepada konsep ‘asabiyyah yang bernilai positif. Sebagaimana yang dijelaskan Ibn Khaldun (t.th.) iaitu `asabiyyah yang melahirkan semangat dan kuasa bagi hidup bernegara. Ia merefleksikan semangat untuk membela kebenaran dan menegakkan keadilan. Jadi, ia lebih berkonotasi kepada semangat patriotisme, perasaan cinta dan menghormati nilai dan kehidupan yang dianuti serta kesediaan untuk berkorban jiwa dan material bagi mempertahankan negara daripada sebarang bentuk pencerobohan dan ketidakadilan (Mohd. Nasir 2005). Menurut Idris Zakaria (2014) pula, teori `asabiyyah ini cukup bermakna dan mempunyai kekuatan bagi menjayakan kesatuan ummah, agama dan peradaban yang besar. Hal ini disebabkan ia dibina di atas dasar persamaan akidah dan persamaan pandangan moral sehingga integrasi keyakinan dan ‘asabiyyah dalam konteks berbangsa dan bernegara menjadi penting bagi melahirkan kekuatan dan semangat perpaduan (Asad 1999). Walau bagaimanapun, Islam menolak bentuk nasionalisme dan fahaman ‘asabiyyah yang justeru mengarah ke perbuatan zalim dan merampas hak orang lain. Ini disebabkan karakter agama bersifat menghapus rasa hasad dan dengki di antara individu dalam masyarakat (Ibn Khaldun t.th.; Idris Zakaria 2014).

Menurut Natsir, Islam mengiktiraf keanekaragaman yang wujud di antara manusia. Pada hakikatnya prinsip kebangsaan Islam tidak bercanggah dengan fakta yang menyebutkan kepelbagaian bangsa. Al-Quran menjelaskan bahawa manusia itu diciptakan berbilang kaum dan bangsa, (shu'uban wa qabai'la) agar saling mengenali dan saling menghargai antara satu sama lain. Kepelbagaian bangsa dan kaum mengajarkan seseorang untuk hidup penuh toleransi menghormati perbezaan daripada kelompok lain. Oleh sebab itu, menurut Natsir apabila fahaman kebangsaan atau nasionalisme itu berteraskan kepada Islam, walaupun jumlah bilangan non-muslim sebagai kaum minoriti, iaitu sekitar 15\% daripada purata populasi penduduk Indonesia yang menganut agama Islam, tapi hak kaum minoriti dalam mengamalkan agamanya tetap terjamin. Jadi, pengertian kebangsaan yang dikonsepsikan Natsir iaitu sebuah ikatan yang kuat dan melahirkan rasa persaudaraan yang dibina atasa dasar persamaan keimanan kepada Allah (s.w.t.) Ikatan persaudaraan ini bermatlamatkan reda Allah (s.w.t.) dalam hidup bernegara dan berbangsa yang ia juga mengimplikasikan nilai toleransi dan penghormatan ke atas golongan minoriti yang berlainan dari segi pandangan ataupun keyakinan. Makna persatuan kebangsaan ini yang dikehendaki oleh Islam iaitu sebuah persatuan yang berdasarkan kebenaran dan kesejahteraan (unity through truth, unity at the cost of truth and human well being) (Mohammad Natsir 1971, 2001).

\section{Demokrasi Islam}

Menurut Natsir, demokrasi dalam Islam lebih kepada makna theistic democracy iaitu sebuah negara yang dibangun atas dasar kesepakatan, musyawarah, keadilan dan toleransi yang berpedomankan kepada al-Quran dan al-Sunnah dengan maksud untuk meraih kesejahteraan di dunia mahupun di akhirat. Demokrasi menurut Natsir adalah satu falsafah yang tidak hanya terbatas pada sistem pentadbiran negara saja. Ia suatu pandangan hidup yang melingkupi aspek rohani dan jasmani. Makna demokrasi itu meliputi pelbagai aspek dan aktiviti hidup ini. Menurut Natsir lagi, demokrasi secara umum dapat dibahagikan kepada dua bahagian. Pertama, demokarsi politik yang menjamin kemerdekaan berfikir, berbicara dan berhimpun, Kedua, demokrasi ekonomi yang menjamin keadilan sosial bagi setiap anggota masyarakat. Perkara yang demikian itu termasuk daripada bahagian kemaslahatan manusia secara rohani dan jasmani. Maka kita dapati semangat Islam itu mendorong manusia ke arah demokrasi, yakni satu bentuk demokrasi yang berada di bawah kawalan hukum. Pada kakikatnya, ajaran Islam sendiri menolak pelbagai bentuk kezaliman dan kediktatoran (Mohammad Natsir 2001, 2007, 2008b; M. Asri 2009; Audrey 2012). 
Makna demokrasi dalam Islam, menurut Natsir adalah usaha untuk mendahulukan kebenaran di atas kepentingan individu ataupun golongan sehingga bentuk demokrasi itu memberikan ruang kepada rakyat untuk mengkritik, menegur, membetulkan pemerintahan yang berlaku zalim. Jika tidak cukup dengan kritikan dan teguran, Islam memberikan hak kepada rakyat untuk menentang pelbagai bentuk kezaliman yang terjadi atas nama negara (Mohammad Natsir 2008). Adapun jika berlaku bantahan kepada kerajaan bukan bererti rakyat berhak untuk melawan secara sewenang-wenang, akan tetapi ia adalah mesti dilakukan sesuai dengan prosedur hukum dan undang-undang yang diakui oleh Islam, iaitu dengan menjunjung tinggi prinsip-prinsip keadilan, musyawarah dan toleransi. Dengan demikian, demokrasi dalam hidup bernegara betul-betul menjamin keberlangsungan hidup bermasyarakat secara lebih baik. Walau bagaimanapun, didapati Natsir (2008b) juga bersetuju dengan butiran makna demokrasi yang dikonsepsikan oleh Presiden Franklin D. Roosevelt sebagai penjamin untuk freedom of expression (kebebasan untuk berbicara), freedom of religion (kebebasan untuk beragama), freedom from want (kebebasan daripada kekurangan) dan freedom from fear (kebebasan daripada ketakutan.

Di samping itu, ketegasan hukum dan penegakan keadilan di tengah-tengah masyarakat adalah faktor yang penting dalam menjaga demokrasi. Ini kerana menurut Natsir, proses demokrasi dalam hidup bernegara tidak akan pernah tercapai bila ia tidak berlandaskan kepada prinsip keadilan dan rasa persamaan di hadapan hukum. Bagi menegakkan keadilan dan rule of law sebagai orientasi hukum hidup bernegara, Islam meletakkan beberapa pedoman. Antaranya adalah kedaulatan hukum di atas semua warganegara mahupun penguasa, kemerdekaan hakim dalam keputusannya, antara pemerintah dan rakyat berlaku pengawasan rakyat dan sokongan rakyat yang berdasarkan jiwa akhlaq al-karimah. Daripada pemaparan tentang konsep politik dan kenegaraan yang dikemukakan oleh Natsir, dapatlah dirumuskan, antara dasar utama dalam pembentukan negara adalah negara berdiri di atas dasar dan nilai agama, berpegang teguh kepada nilai demokrasi yang berteraskan kedaulatan Ilahi, membangun tolerasi ke atas setiap golongan dan kelompok, membangun kekuatan ekonomi dan sosial yang berpedomankan keadilan dan kesejahteraan kepada seluruh rakyat. Semua ini merujuk kepada apa yang diyakini oleh Mohammad Natsir bahawa Islam adalah satu-satunya agama yang memiliki dasar kehidupan manusia secara utuh, meliputi aspek sosial, politik dan negara. Ini memandangkan ajaran Islam mengkehendaki berlakunya kesejahteraan dan keadilan sejagat. Adalah wajar selaku pimpinan tertinggi Parti Masyumi, dalam salah satu perhimpunan dewan rakyat, secara lantang Natsir menuntut dasar perlembagaan negara Republik Indonesia berdasarkan Islam, yakni negara demokrasi berdasarkan Islam (Mohammad Natsir 1987, 2001).

\section{References}

Ahmad Suhelmi. 2002. Polemik Negara Islam Soekarno versus Natsir. Jakarta: Teraju.

Anwar Harjono \& Lukman Hakiem. 1995. M. Natsir sumbangan dan pemikirannya untuk Indonesia. Jakarta: Media Da`wah.

Asad, Muhammad. 1999. The Principle of state and government in Islam. Kuala Lumpur: Islamic Book Trust.

Audrey, Kahin R. 2012. Islam, nationalism and democracy: A political biography of Mohammad Natsir. Singapore: NU Press.

Burhan D. Magenda. 2008. M. Natsir sebagai politisi dan negarawan. Dlm. Lukman Hakim (pnyt.). M. Natsir di panggung sejarah Republik. Jakarta: Republika.

Dwi Purwoko et al. 2001. Negara Islam dalam percikan pemikiran H. Agus Salim, KH. Mas Mansur, Mohd. Natsir, KH. Hasyim As ary. Jakarta: Permata Artistika.

Gamal Abdul Nasir Zakaria. 2003. Mohammad Natsir pendidik ummah. Bangi: Universiti Kebangsaan Malaysia.

Harjono, Anwar. 2001. Pemikiran dan perjuangan Mohammad Natsir. Jakarta: Pustaka Firdaus. 
Hendra Gunawan. 2000. M. Natsir Darul Islam: Studi kasus Aceh dan Sulawesi Selatan tahun 1953-1958. Jakarta: Media Da`wah.

Hilderst Geertz. 1981. Aneka budaya dan komunitas Indonesia. Transl. A. Rahman Zainuddin. Jakarta: Pulsar Press.

Howard, M. Federspiel. 2006. Indonesian Muslim intellectuals of the 20th Century. Singapore: Institue of Southeast Asian Studies.

Ibn Khaldun, `Abd al-Rahman Muhammad. t.th. Muqaddimah. Cairo: Maktabat al-Nahdah.

Ibn Taymiyyah, Taq al-Din Abu al-`Abbas Ahmad. 1991. Al-Siyasah al Shar iyyah fi Islah al- Ra i wa al-Ra iyyah. Morocco: Dar al-Afaq al-Jadin.

Idris Zakaria. 2014. Falsafah Politik Islam dan kepentingan di Malaysia. Bangi: Penerbit UKM.

Iqbal, Muhammad. 1948. Speeches and statements of Iqbal. Shamloo (pnys.). Lahore: Al-Manar Academy.

2006. The Reconstruction of religious thought in Islam. Selangor: Masterpiece Publications Sdn. Bhd.

Kahin, George Mc.Turnan. 1970. Nationalism and revolutionism in Indonesia. New York: Cornell University.

1995. Mohammad Natsir (1908-1993) sebuah kenangan. Dlm. M. Natsir Sumbangan dan Pemikirannya untuk Indonesia. Jakarta: Media Dakwah.

M. Amin Rais. 1988. Mohammad Natsir the Second Grand Old Man. Dlm. H. Endang Saifuddin Anshari. (pnyt.). Pak Natsir 80 tahun pandangan dan penilaian generasi muda. Jakarta: Media Dakwah.

Mahmud Yunus. 1982. Sejarah pendidikan di Indonesia. Jakarta: Hidayat Agung.

Mas`oed Abidin. 2012. Gagasan dan gerak dakwah Natsir. Yogyakarta: Gre Publishing.

al-Mawardi, Abu al-Hasan `Al ibn Muhammad al Habib, 1989. Al-Ahkam al-sultaniyyah wa alwilayat al-diniyyah. Kuwait: Maktabah Dar Ibn Qutaybah.

Mohammad Natsir . 1969. Islam dan Kristen di Indonesia. Jakarta: Media Dakwah. 1971. Di bawah nungan sisalah. Jakarta: Sinar Hudaya.

1987. Demokrasi di bawah hukum. Jakarta: Media Dakwah.

2000. Islam sebagai dasar negara. Jakarta: Media Dakwah.

2001. Agama \& negara dalam perspektif Islam. Jakarta: Media Dakwah.

2008. Capita Selecta I. Jakarta: Media Dakwah.

2008a. Capita Selecta II. Jakarta: Medai Dakwah.

2008b. Capita Selecta III. Jakarta: Media Dakwah.

Mohd. Asri Abdul, Mohd Halim Abdul Hamid \& Rahmah Hashim (pnyt.). 2009. Mohammad Natsir: Berdakwah di jalur politik, berpolitik di jalur dakwah. Selangor: Wadah Pencerdasan Umat Malaysia.

Mohd. Nasir Omar. 2005. Gagasan Islamisasi Ilmu. Kuala Lumpur: Utusan Publications \& Distibutors Sdn. Bhd.

Noer, Deliar. 1984. Gerakan Moderen Islam di Indonesia 1900-1942. Jakarta: LP3ES.

Purwoko, Dwi. (pnyt.). 2001. Negara Islam, percikan pemikiran H. Agus Salim, KH. Mas. Mansur, Mohammad Natsir, KH. Hasyim Asy'ari. Depok: Permata Artistika Kreasi.

Ramly Hutabarat. 1999. Hukum dan demokrasi menurut M. Natsir. Jakarta: Biro Riset Dewan Dakwah Islamiyah.

Sohirin Mohammad Solihin. 2013. Mohammad Natsir: Intellectualism and activism in modern age. Malaysia: IIUM Press.

Susilo Bambang Yudoyono. 2008. Memetik keteladanan, keikhlasan, dan semangat juang Pak Natsir. Dlm. Lukman Hakim (pnyt.). M. Natsir di panggung sejarah Republik. Jakarta: Republika. 